\title{
INTEGRASI SIMULASI DALAM AUGMENTED REALITY PADA SISTEM PERNAPASAN MANUSIA
}

\author{
Selo Aji'), Eneng Tita Tosida'), Aries Maesya ${ }^{3)}$ \\ 1, 2 \& 3)Program Studi IImu Komputer, FMIPA, Universitas Pakuan, Bogor, Indonesia
}

Corresponding Author: seloaj167@gmail.com

Article history: received 25 September 2018; revised 1 Desember 2018; accepted 5 Desember 2018

\begin{abstract}
Abstrak
Sistem pernapasan adalah proses mengambil oksigen, melepaskan CO2 dan menggunakan energi yang dihasilkan. Sistem pernapasan terdiri dari rongga hidung, faring, laring, trakea, cabang bronkial, dan paru-paru. Sistem pernapsan pada manusia dapat dipelajari secara langsung dan tidak langsung. Namun, sumber belajar ini kurang menarik dan kurang interaktif. Oleh karena itu teknologi Augmented reality (AR) adalah solusi yang tepat untuk mengatasi masalah ini. Penelitian ini bertujuan untuk membuat aplikasi menggunakan teknologi augmented reality Tracking Markerkess Based dengan mengintegrasikan simulasi pernaapasan dengan animasi 3d. Sehingga memanfaatkan fitur kamera pada perangkat smartphone untuk mendeteksi permukaan datar, simuali animasi 3D akan muncul. Augmented reality adalah penggabungan suatu objek yang ada di dunia nyata (virtual) ke duania nyata dalam bentuk $2 D$ atau 3D yang dapat dilihat dan didengar secara real time. Metode yang digunakan dalam penelitian ini adalah Markerless Based Tracking. Aplikasi integrase simulai dalam system pernapasan manusia augmented reality dapat digunakan oelh siswa, mahasiswa, generasi milenial dan masyarakat umum, sehingga memanfaatkan fitur kamera pada perangkat smartphone untuk mendeteksi permukaan data, simulasi animasi 3D akan muncul. Aplikasi ini akan berjalan pada platform mobile Android 7.0 (Nougeat) dan mendukung ArCore dengan kapasitas aplikasi $36,4 M B$.
\end{abstract}

Keywords : augmented reality (AR), markerless based tracking, respiratory sistem.

\begin{abstract}
The respiratory system is a process of taking oxygen, releasing $\mathrm{CO} 2$ and using the energy produced. The respiratory system consists of the nasal cavity, pharynx, larynx, trachea, bronchial branches and lungs. The respiratory system in humans can be studied directly and indirectly. However, these learning resources are less interesting and less interactive. Therefore $A R$ (Augmented reality) technology is the right solution to overcome this problem. This study aims to create applications using Markerless Based Tracking augmented reality technology by integrating breathing simulation with $3 D$ animation. So by utilizing the camera features on smartphone devices to detect flat surfaces, a simulation of $3 D$ animation will appear. Augmented reality is the incorporation of an object that exists in cyberspace (virtual) into the real world in the form of $2 D$ or $3 D$ that can be seen and heard in real time. The method used in this research is Markerless Based Tracking. Simulation integration application in augmented reality human respiratory system can be used by students, college students, millennial generation and the general public, so that by utilizing the camera features on smartphone devices to detect flat surfaces, a simulation of $3 D$ animation will appear. This application will run on the Android 7.0 mobile platform (Nougat) and support ARCore with an application capacity of 36.4MB.
\end{abstract}

Keywords : augmented reality (AR), markerless based tracking, respiratory system. 


\section{Pendahuluan}

Anatomi tubuh manusia adalah ilmu yang mempelajari struktur tubuh manusia dengan cara menguraikan tubuh manusia menjadi bagian yang lebih kecil kebagian yang paling kecil, dengan cara memotong atau mengiris tubuh manusia kemudian dipelajari dan diperiksa menggunakan mikroskop. Anatomi tubuh manusia disusun ke dalam beberapa bagian tubuh, salah satunya adalah sistem pernapasan. Sistem pernapasan terdiri dari rongga hidung, faring, laring, trakea, percabangan bronkus, dan paru-paru [1]. Sistem pernapasan pada manusia dapat dipelajari secara langsung dan secara tidak langsung. Pembelajaran secara langsung dilakukan dengan adanya interaksi dengan tubuh manusia itu sendiri, biasanya dilakukan oleh mahasiswa kedokteran. Namun pembelajaran secara langsung memiliki banyak kendala diantaranya biaya, psikologis, resiko bahaya dan sebagainya. Adapun pembelajaran secara tidak langsung dapat dilakukan melalui buku, E-book dan video. Akan tetapi sumber pembelajaran tersebut kurang menarik dan kurang interaktif. Maka dari itu teknologi AR (Augmented reality) adalah solusi yang tepat untuk mengatasi masalah tersebut.

Augmented reality adalah penggabungan suatu objek yang ada di dunia maya (virtual) ke dalam dunia nyata yang berbentuk $2 \mathrm{D}$ atau $3 \mathrm{D}$ yang dapat dilihat dan didengar secara real time [2]. Teknologi AR dapat menyisipkan suatu informasi tertentu ke dalam dunia digital dan menampilkannya di dunia nyata dengan bantuan media seperti webcam, komputer, smartphone maupun kacamata khusus [3]. AR dapat dikembangkan dalam perangkat smartphone yang mana saat ini sudah banyak digunakan. Smartphone adalah ponsel yang melakukan banyak fungsi komputer biasanya memiliki antar muka layar sentuh, akses internet, dan system operasi yang mampu menjalankan aplikasi yang diunduh [4]. Pemanfaatan teknologi dalam proses pembelajaran dengan berbasis multimedia salah satunya dapat diimplementasikan melalui AR, dengan harapan mampu bersinergi dengan konsep pembelajaran tematik terpadu [5].

Penelitian sebelumnya telah dibuat aplikasi AR anatomi tubuh manusia menggunakan metode marker yang bertujuan untuk untuk memasukkan teknologi Augemented Reality berbasis android ke dalam sebuah gambar yang menarik sebagai alat bantu media pembelajaran pelajar SMP kelas VIII tentang anatomi tubuh manusia dalam mata pelajaran Biologi. Menerapkan metode Augmented Reality pada anatomi tubuh manusia pada proses pembelajaran para siswa tidak perlu membawa buku paket pelajaran cukup dengan ponsel kamera berbasis android, selain itu pada aplikasi ini terdapat animasi sistem reproduksi, sistem pencernaan dan sistem peredaran darah yang diharapkan dapat mempermudah serta menarik minat para siswa dalam memahami materi. [6], namun aplikasi tersebut tidak fleksibel, seperti harus adanya ilustrasi hitam dan putih, persegi dengan batas hitam, tebal dan latar belakang putih (marker based tracking) sehingga mengakibatkan aplikasi augmented reality menjadi ketergantungan karena aplikasi hanya dapat dijalankan jika marker tersedia. Metode lain yang dapat diimplementasikan dalam AR adalah metode Markerless, metode ini lebih praktis dalam penerapan pada Augmented reality menggunakan smartphone karena dalam penggunaannya dapat digunakan dimanapun tanpa mencetak marker.

Penelitian ini bertujuan untuk memudahkan para ahli patologi forensik dalam melakukan proses pemeriksaan pada kematian seseorang dengan meminimalisir kerusakan yang terjadi pada organ tubuh korban baik secara internal maupun ekternal. Menerapkan Augmented Reality pada proses forensik, membantu ahli patologi selama otopsi tanpa perlu mendatangkan mayat ke Laboratorium Radiologi, cukup melalui visualisasi intuitif data forensik dan mengevaluasi kelayakannya dengan memperkirakan pose kamera berdasarkan pada data permukaan bertekstur anatomi tubuh dan data kedalaman yang memungkinkan penerapan AR. [7].

Augmented reality semakin diterapkan dipendidikan kedokteran. Peneliti menggambarkan pengembangan aplikasi web yang meningkatkan kemampuan pemahaman pembelajaran medis yang berkaitan dengan anatomi hati manusia melalui Augmented Reality. Penulis melakukan evaluasi dalam dua sisi yang berbeda. Pertama, mengevaluasi kelayakan tiga dimensi modul jantung manusia menggunakan satu simpatisan di bawah pengawasan seorang ahli. Kedua, mengidentifikasi masalah kegunaan melalui metode Walkthrough Cognitif. Melalui implementasi ini pendidik dapat berbagi pengetahuan melalui objek virtual kepada mahasiswa kedokteran di Medical School Aristotle, University of Thessaloniki, Yunani. [8]. 
Penelitian ini bertujuan untuk memudahkan pembelajaran anatomi tubuh manusia, sehingga siswa tidak lagi terpaku pada buku teks. Metode yang digunakan yaitu waterfall. Metode ini meliputi perencanaan, desain, implementasi dan pengujian. Penggunaan Augmented reality pada proses pemahaman siswa terhadap materi anatomi tubuh manusia menjadikan bahan pembelajaran lebih menarik karena adanya interaksi secara langsung dengan objek 3D [9].

Penelitian ini dibuat untuk mengatasi kendala dalam memvisualisasikan pelajaran anatomi tubuh manusia dengan menggunakan teknologi Augmented Reality. Metode yang digunakan dalam sistem ini adalah marker pada platform komputasi mobile. Fitur yang terdapat dalam aplikasi ini secara interaktif menampilkan seluruh tubuh atau bagian-bagian organ tubuh manusia. [10].

Penelitian-penelitian yang telah ada hanya memfokuskan terhadap pembaharuan model pembelajaran dari buku teks menjadi bentuk visualisasi dalam bentuk 3D, tanpa adanya evaluasi analisa kuantitatif dan peningkatan kinerja sistem dan service dari sistem yang telah ada. Simulasi merupakan tiruan dari sebuah sistem dinamis dengan menggunakan model komputer untuk melakukan evaluasi dan meningkatkan kinerja sistem. Selain sebagai bahan evaluasi dan peningkatan kinerja sistem, simulasi ini dapat dilakukan untuk meninjau proses pengambilan keputusan dengan menyediakan bukti objektif [11].

Berdasarkan paparan yang sudah dijelaskan, dapat disimpulkan bahwa teknologi AR dapat digunakan sebagai media informasi yang fleksibel, sehingga dibutlah penelitian mengenai "Integrasi Simulasi dalam Augmented reality Sistem Pernapasan Manusia" dengan harapan dapat membantu siswa maupun mahasiswa dalam memudahkan pemahaman materi Sistem Pernapasan Manusia. Tujuannya untuk membuat aplikasi menggunakan teknologi Markerless Based Tracking augmented reality dengan mengintegrasikan simulasi pernapasan dengan animasi 3D.

\section{Metode Penelitian}

Dalam penelitian ini metode yang digunakan adalah Multimedia Development Life Cycle, dimana metode ini memiliki 6 tahapan, yaitu concept, design, material collecting, assembly, testing dan distribution. Gambaran metode ini dapat dilihat dalam Gambar 1.

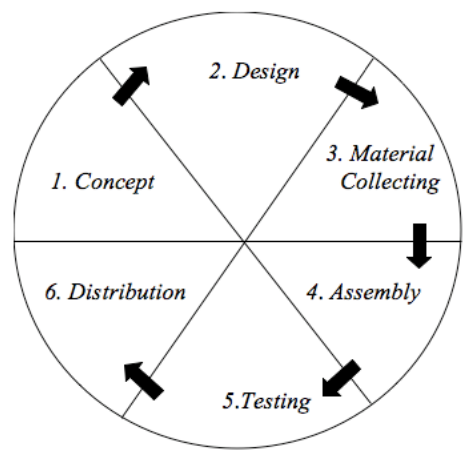

Gambar 1. Diagram Multimedia Development Life Cycle.

Tahap concept (pengkonsepan) yaitu menentukan tujuan, termasuk identifikasi audiens, macam aplikasi (presentasi, interaktif, dan lain-lain), tujuan aplikasi (informasi, hiburan, pelatihan dan lain-lain) dan spesifikasi umum. Dasar aturan untuk perancangan juga ditentukan pada tahap ini, seperti ukuran aplikasi, target, dan lain-lain. Dalam tahapan ini ada beberapa tahap yang perlu diperhatikan, antara lain menentukan tujuan aplikasi yaitu untuk memberikan informasi sistem pernapasan manusia. Deskripsi Aplikasi Implementasi Augmented reality ini berjalan dan dioperasikan pada perangkat bersistem operasi android.

Tahap Design (Desain) adalah tahap pembuatan spesifikasi mengenai gaya, arsitektur, bentuk, tampilan, dan kebutuhan material/bahan untuk pengembangan, pada tahap ini agar mempermudah pembuatan aplikasi dimana seluruh obyek multimedia dibuat dengan berdasarkan interface flowchart, struktur navigasi, interface storyboard dan flowchart interface yang berasal dari tahap desain. 
Pada tahapan ini, materi terkait bahan ajar/materi pembelajaran di dapatkan dari wawancara dan buku biologi yang didapat di perpustakaan. Untuk mendapatkan data berupa foto sistem pernapasan yang di pilih untuk mengetahui bagaimana sistem organ berfungsi, sedangkan untuk materi terkait Augmented reality, penulis mendapatkan materi dari buku referensi, jurnal dan internet.

Tahap (pembuatan) adalah tahap dimana semua objek atau bahan Aplikasi disatukan. Pembuatan aplikasi didasarkan pada rancangan design yang telah dibuat. Semua objek atau material dibuat dan digabungkan menjadi satu aplikasi yang utuh. Dalam tahapan ini digunakan beberapa aplikasi seperti blender untuk membuat $3 \mathrm{~d}$ dan animation, substance painter untuk texturing, unity $3 \mathrm{~d}$, dan ARCore untuk dikembangkan.

Tahap testing disebut juga sebagai tahap uji coba, tahap uji coba sendiri merupakan tahapan dimana aplikasi yang telah dibuat digunakan untuk pertama kalinya setelah aplikasi dibangun, untuk mengetahui kekurangan, kelebihan, ataupun kecocokan dengan rancangan yang telah dibuat. Uji coba yang dilakukan terdiri dari: Uji coba Struktural yaitu tahap proses pengecekan apakah aplikasi yang di bangun sudah sesuai dengan rancangan yang dibuat dalam proses desain. Uji coba Fungsional yaitu tahap proses pengecekan apakah setiap tombol yang ada dalam aplikasi ini sudah sesuai dengan fungsinya atau tidak. Dan Uji coba Validasi yaitu tahap pengecekan data informasi yang ditampilkan oleh sistem sesuai kebenarannya dengan apa yang ada di buku yang digunakan.

Tahap distribution dilakukan dengan mengcompile aplikasi ke dalam format apk. setelah lolos dalam tahapan uji coba yang telah ditentukan selanjunya aplikasi yang sudah dibuat dalam bentuk apk bisa digunakan oleh masyarakat, ataupun bisa di distribusikan ke dalam jaringan penjualan aplikasi seperti playstore.

Alat yang digunakan dalam penelitian ini meliputi pentab, laptop, handphone dan mouse. Sedangkan untuk bahan yang digunakan dalam penelitian ini adalah Blender, Substance Painter, Adobe Photoshop, Unity 3d dan ARCore.

\section{Hasil dan Pembahasan}

Simulasi merupakan tiruan dari sebuah sistem dinamis dengan menggunakan model komputer untuk melakukan evaluasi dan meningkatkan kinerja sistem. Selain sebagai bahan evaluasi dan peningkatan kinerja sistem, simulasi ini dapat dilakukan untuk meninjau proses pengambilan keputusan dengan menyediakan bukti objektif [11]. Pendekatan simulasi diawali dengan pembangunan model sistem nyata. Model tersebut harus dapat menunjukkan bagaimana berbagai komponen dalam sistem saling berinteraksi sehingga benar-benar menggambarkan perilaku sistem. Setelah model dibuat maka model tersebut ditransformasikan ke dalam program komputer sehingga memungkinkan untuk disimulasikan. Gambaran dari aneka cara mempelajari sistem dapat dilihat pada Gambar 2.

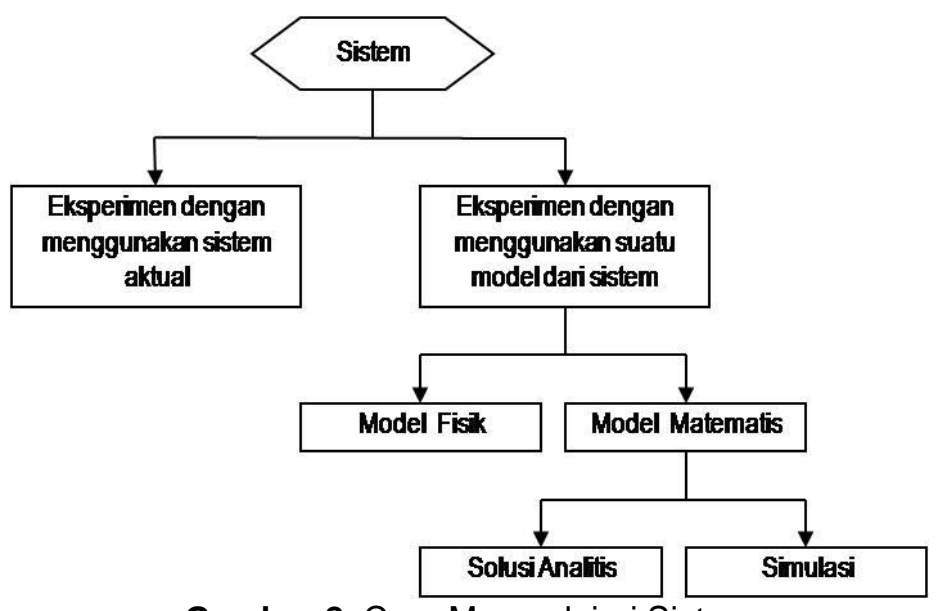

Gambar 2. Cara Mempelajari Sistem

Teknologi Augmented Reality (AR) adalah sebuah teknologi visual yang menggabungkan objek atau dunia virtual ke dalam tampilan dunia nyata secara real time. Dalam pembuatan 
KOMPUTASI (Jurnal IImiah IImu Komputer dan Matematika)

Vol.16, No.1, Januari 2019, Hal. $213-226$

P-ISSN: 1693-7554, E-ISSN: 2654-3990

https://journal.unpak.ac.id/index.php/komputasi

aplikasi integrasi simulasi augmented reality sistem pernapasan manusia menggunakan teknologi Markerless Based Tracking untuk media informasi berbasis android ini yaitu dimulai dari menganalisis. Kemudian dilanjutkan dengan merancang desain interface aplikasi. Tahap selanjutnya adalah implementasi interface yang sudah dirancang ke dalam bentuk sistem. Untuk selanjutnya dilakukan pengujian terhadap aplikasi untuk mengetahui apakah aplikasi terdapat kesalahan atau error. Hasil dari User Interface aplikasi dapat dilihat pada Tabel 1.

Tabel 1. Hasil User Interface.

\begin{tabular}{|c|c|c|}
\hline Halaman & Keterangan \\
\hline Aplikasi & Halaman ikon aplikasi adalah tampilan aplikasi sistem \\
Pernapasan yang telah diinstal diperangkat android. \\
Menu
\end{tabular}




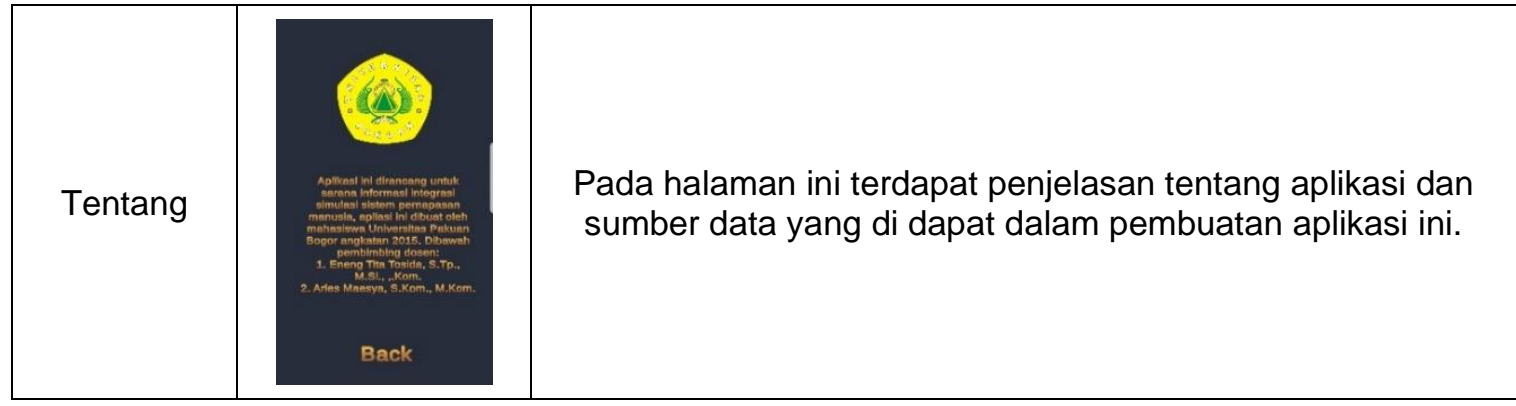

Penerapan augmented reality (AR) dengan metode Markerless Based Tracking untuk media informasi sistem pernapasan manusia ini dapat dijalakan pada OS Android minimal naougat 7.0 dan mendukung ARCore. Menurut [12], ARCore merupakan Software Development Kit (SDK) untuk android dengan versi android minimal naougat 7.0. Implementasi Augmented reality ini dapat menampilkan objek 3D secara virtual dan real-time dengan memberikan informasi tentang Simulasi Sistem Pernapasan Manusia.

Metode Markerless Based Tracking ini tentunya ada perbedaan dengan metode sebelumnya yaitu marker based tracking. Metode markerless ini tidak perlu lagi menggunakan kertas sebagai media deteksi, tetapi dengan metode ini kamera bisa scan langsung objek yang diinginkan. Pernyataan ini diperkuat oleh penelitian yang telah dilakukan Dany, dkk (2018), metode markerless dapat mengidentifikasi suatu objek di dunia nyata tanpa adanya marker khusus. ARCore memberikan kemudahan yang ia mampu mendeteksi permukaan datar, seperti meja dan lantai. Dengan demikian, pengindentifikasian yang cukup cahaya dan memiliki ukuran objek yang sesuai maka akan tampil simulasi sistem pernapasan. Menurut [12], penggunaan ARCore memiliki 3 teknologi utama, yaitu: Motion Tracking dimana memungkinkan ponsel untuk memahami dan melacak posisinya relatif terhadap dunia, Environmental Undestanding memungkinkan ponsel mendeteksi ukuran dan lokasi permukaan horisontal datar seperti tanah atau meja kopi dan Light Estimation memungkinkan telepon untuk memperkirakan kondisi pencahayaan saat ini di lingkungan.

Manusia memiliki kapasitas paru-paru sekitar $500 \mathrm{ml}$ udara, namun tidak semua udara tersebut oksigen. Proses pernapasan dapat dipengaruhi oleh beberapa faktor salah satunya adalah aktivitas tubuh. Dalam keadan lelah paru-paru akan membutuhkan lebih banyak oksigen yang masuk ke dalam tubuh untuk menstabilkan kadar oksigen didalam darah dalam waktu tertentu [13]. Maka dalam keadaan lelah manusia akan menghirup napas lebih cepat jika dibandingkan dengan keadaan normal, hal ini dikdarenakan sedikitnya kadar oksigen didalam tubuh sehinngga memicu paru-paru untuk menghirup napas lebih cepat. Di dalam simulasi terdapat perbedaan yaitu dimana $1500 \mathrm{ml}$ udara (tidak normal) animasi masuk dan keluarnya udara akan bergerak lebih cepat dengan $300 \mathrm{ml}$ oksigen, $1200 \mathrm{ml}$ gas lain (uap air dan karbon dioksida) dibanding dengan $500 \mathrm{ml}$ udara yang dihirup (normal) dengan $100 \mathrm{ml}$ oksigen, $400 \mathrm{ml}$ gas lain (uap air dan karbon dioksida) dan akan dalam keadaan diam animasi sistem pernapasan tersebut apabila dalam keadaan $0 \mathrm{ml}$ (tidak bernapas) kemudian umumnya manusia 30-50 detik dapat bertahan menahan nafas.

Tahap berikutnya adalah uji coba sistem aplikasi ini dengan cara dijalankan pada Smartphone Android. Pengujian ini dilakukan untuk mengetahui kekurangan atau kelemahan dari aplikasi, seperti menu tidak berjalan, tombol tidak berfungsi dan sebagainya. Dalam uji coba aplikasi terdapat beberapa tahap yang akan dilakukan, yaitu :

Uji coba struktural ini merupakan tahap untuk pengecekan aplikasi yang dibuat apakah sudah sesuai dengan rancangan yang sebelum nya sudah di buat dalam tahap desain. Pada tahap ini dilakukan pengecekan semua desain, tampilan, warna dan button sesuai dengan yang diinginkan. Berdasarkan uji coba yang telah dilakukan maka secara keseluruhan desain setiap halamannya berfungsi dan sesuai. Hasil ini dapat dilihat pada Tabel 2 
Tabel 2. Uji Coba Struktural

\begin{tabular}{|c|l|c|}
\hline No & \multicolumn{1}{|c|}{ Tampilan Halaman } & Status Percobaan \\
\hline 1 & Halaman Loading Screen & Tampil, Sesuai \\
\hline 2 & Halaman Main Menu & Tampil, Sesuai \\
\hline 3 & Halaman Mulai AR & Tampil, Sesuai \\
\hline 4 & Halaman Petunjuk & Tampil, Sesuai \\
\hline 5 & Halaman Tentang & Tampil, Sesuai \\
\hline
\end{tabular}

Uji coba fungsional ini dilakukan untuk mengetahui apakah sistem yang dibuat sudah berfungsi dengan baik. Pada tahap ini dilakukan percobaan untuk mengetahui apakah fungsi dari setiap tombol atau menu pada halaman dapat berfungsi dengan baik. Berdasarkan uji coba yang telah dilakukan maka secara keseluruhan tombol atau menu pada setiap halaman dapat berfungsi dan berjalan sesuai dengan keinginan Hasil ini dapat dilihat pada Tabel 3

Tabel 3. Uji Coba Fungsional

\begin{tabular}{|c|c|l|c|}
\hline No & Nama Scene & \multicolumn{1}{|c|}{ Tampilan } & Hasil \\
\hline 1 & Scener Spalash Screen & Logo Unity & Berhasil \\
\hline \multirow{4}{*}{2} & \multirow{4}{*}{ Scenen Halaman Utama } & Mulai AR & Berhasil \\
\cline { 3 - 4 } & & Sistem Pernapasan & Berhasil \\
\cline { 3 - 4 } & & Petunjuk & Berhasil \\
\cline { 3 - 4 } & & Tentang & Berhasil \\
\cline { 3 - 4 } & & Exit & Berhasil \\
\hline \multirow{2}{*}{3} & \multirow{2}{*}{ Scene Mulai AR } & Augmented reality & Berhasil \\
\cline { 3 - 4 } & & Kembali & Berhasil \\
\hline \multirow{2}{*}{4} & \multirow{3}{*}{ Scene Sistem Pernapasan } & Next Slide & Berhasil \\
\cline { 3 - 4 } & & Back Slide & Berhasil \\
\cline { 3 - 4 } & & Back Menu & Berhasil \\
\hline 5 & Scene Petunjuk & Back & Berhasil \\
\hline 6 & Scene Tentang & Back & \\
\hline
\end{tabular}

Uji validasi adalah tahap dimana merupakan pengecekan data informasi dari suatu objek apakah sudah sesuai dengan data yang sudah di kumpulkan sebelumnya pada tahap material collecting, dengan kata lain, validasi disini untuk memastikan apakah aplikasi yang dibuat sudah sesuai dengan harapan pengguna atau belum. Di bawah ini merupakan uji coba testing aplikasi untuk mendeteksi objek sistem pernapasan apakah informasi dapat di tampilkan berupa informasi atau tidak. Uji validasi tersebut berdasarkan uji cahaya menggunakan aplikasi Light Meter (Lux Meter) adalah alat yang digunakan untuk mengukur besarnya intensitas cahaya di suatu tempat. Semakin jauh jarak antara sumber cahaya ke sensor maka akan semakin kecil nilai yang ditunjukkan lux meter. Dan juga validasi berdasarkan kemiringan sudut derajat terhadap objek.

Tabel 4. Uji Validasi Berdasarkan Kemiringan.

\begin{tabular}{|c|c|c|c|}
\hline No & Keterangan Uji Coba & Gambar Uji Coba & $\begin{array}{c}\text { Hasil Uji } \\
\text { Coba }\end{array}$ \\
\hline 1. & $\begin{array}{c}\text { Di scan pada jarak } 10-20 \mathrm{~cm}, \\
\text { dengan kemiringan derajat } \\
\text { terhadap objek } 47 \text { derajat. }\end{array}$ & & $\begin{array}{c}\text { Objek tidak } \\
\text { terdeteksi }\end{array}$ \\
\hline
\end{tabular}




\begin{tabular}{|c|c|c|c|c|}
\hline Di scan pada jarak $10-20 \mathrm{~cm}$, \\
dengan kemiringan terhadap \\
objek 50 derajat.
\end{tabular}

Tabel 5. Uji Validasi Berdasarkan Cahaya/Lux

No \begin{tabular}{c|c|c|}
\hline Keterangan Uji Coba & Gambar Uji Coba & $\begin{array}{c}\text { Hasil Uji } \\
\text { Coba } \\
\text { Di scan di dalam ruangan dengan } \\
\text { nilai cahaya/lux 3226lx di hitung } \\
\text { menggunakan aplikasi light meter. }\end{array}$ \\
\hline $\begin{array}{c}\text { Di scan di dalam ruangan dengan } \\
\text { nilai cahaya/lux 9lx di hitung } \\
\text { menggunakan aplikasi light meter. }\end{array}$ & Objek terdekteksi \\
\hline
\end{tabular}

KOMPUTASI, Vol.16, No.1, Januari 2019, Hal. 213 - 226 
KOMPUTASI (Jurnal IImiah IImu Komputer dan Matematika)

Vol.16, No.1, Januari 2019, Hal. 213 - 226

P-ISSN: 1693-7554, E-ISSN: 2654-3990

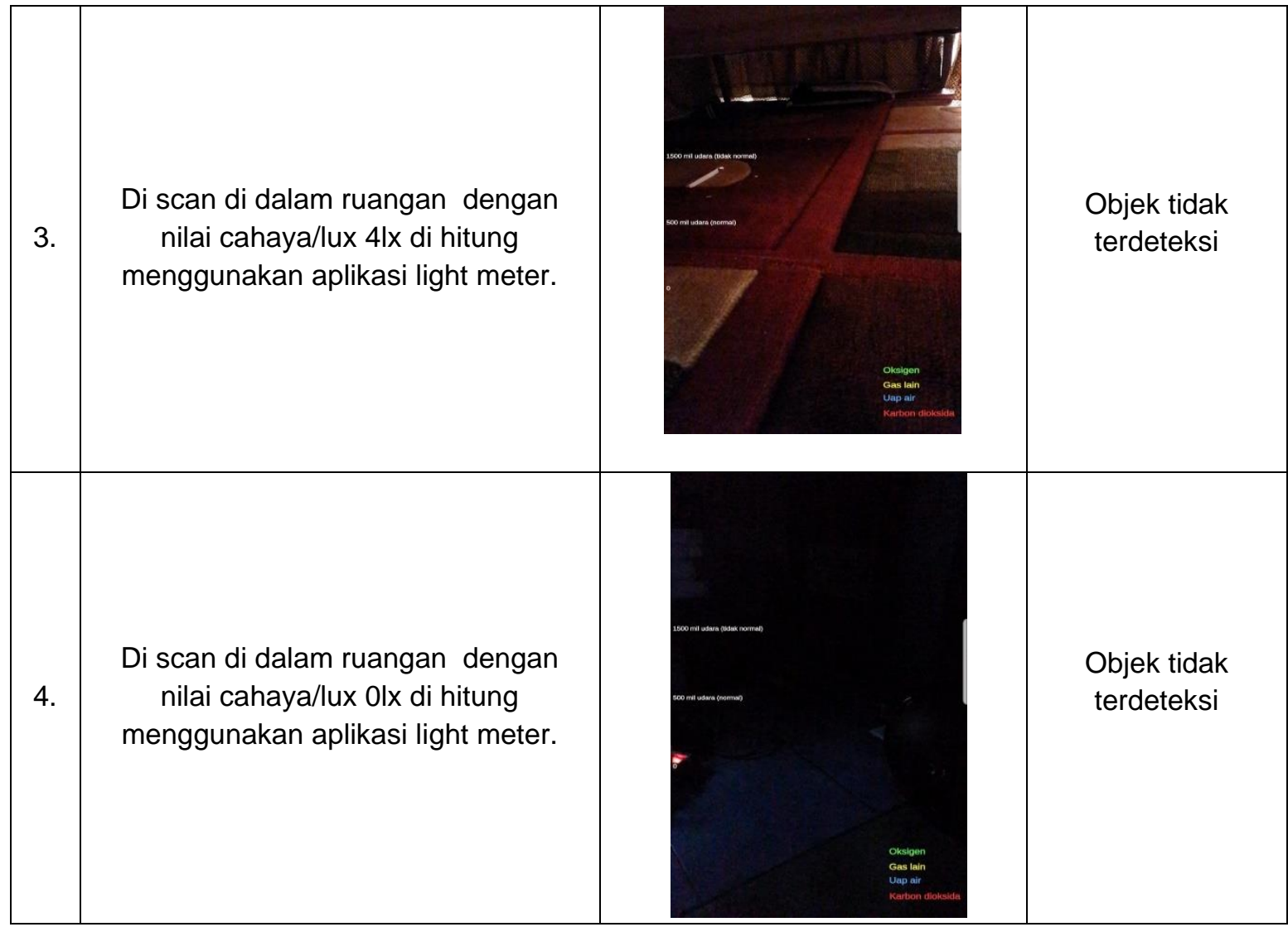

Tabel 6. Uji Validasi Berdasarkan Jarak.

\begin{tabular}{|c|c|c|c|}
\hline No & Keterangan Uji Coba & Gambar Uji Coba & $\begin{array}{c}\text { Hasil Uji } \\
\text { Coba }\end{array}$ \\
\hline 1. & Di scan pada jarak $28 \mathrm{~cm}$ & Objek terdeteksi \\
& & & \\
\hline
\end{tabular}




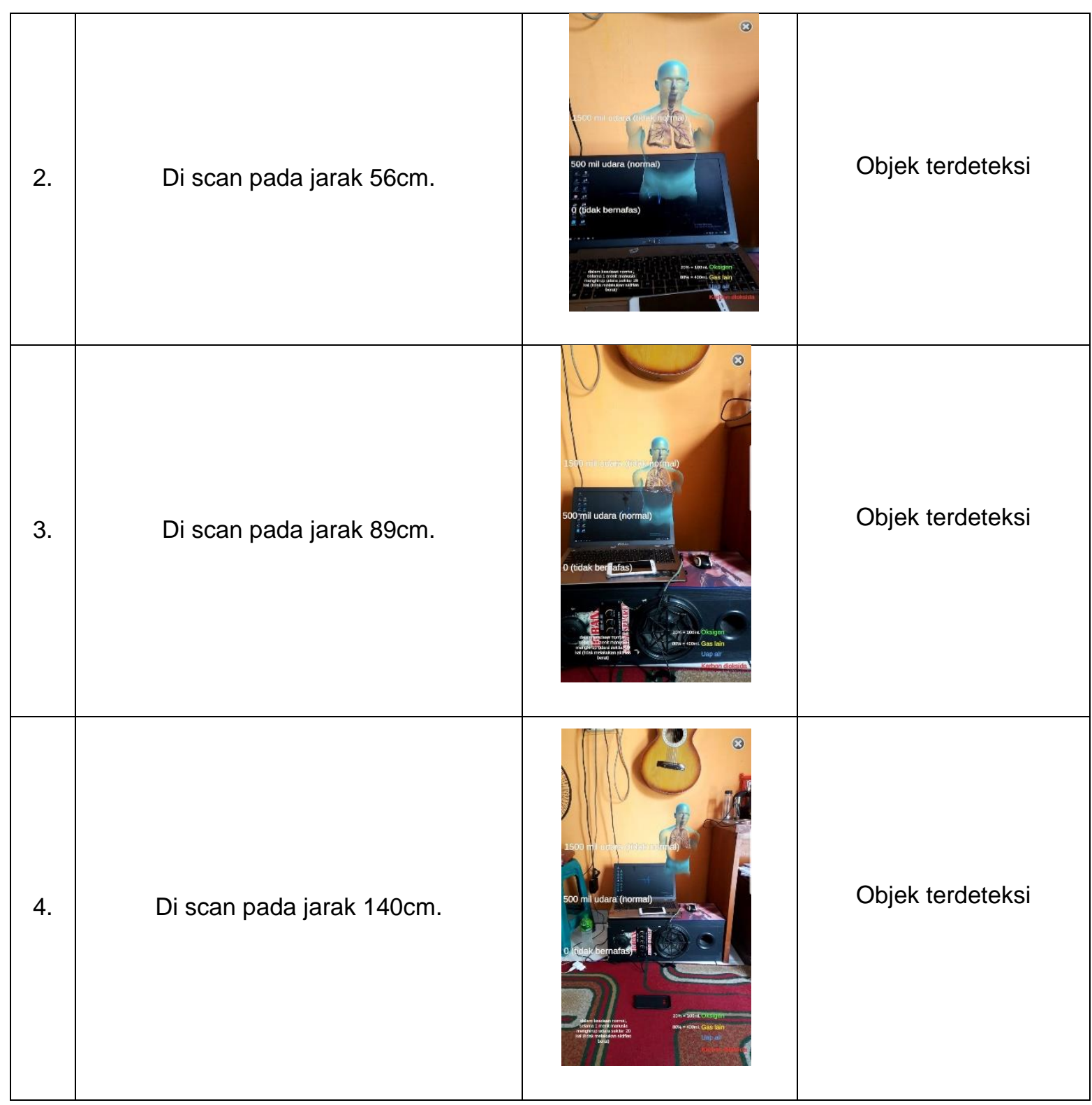

Uji Coba Komputasi dilakukan menggunakan beberapa jenis smartphone sebagai perbandingan kecepatan objek di baca oleh kamera, dalam hal ini objek di uji berdasarkan pixel kamera,RAM, prossesor. 
KOMPUTASI (Jurnal IImiah IImu Komputer dan Matematika)

Vol.16, No.1, Januari 2019, Hal. 213 - 226

P-ISSN: 1693-7554, E-ISSN: 2654-3990

https://journal.unpak.ac.id/index.php/komputasi

Tabel 7. Uji Kompabilitas

\begin{tabular}{|c|c|c|c|}
\hline No & $\begin{array}{l}\text { Merk \& Speksifikasi } \\
\text { Handphone }\end{array}$ & $\begin{array}{l}\text { Kinerja } \\
\text { Aplikasi }\end{array}$ & $\begin{array}{c}\text { Gambar Hasil } \\
\text { Pengujian }\end{array}$ \\
\hline 1. & $\begin{array}{c}\text { Speksifikasi: } \\
\text { - Quad-core (2x2.15 GHz } \\
\text { Kryo \& 2x1.6 GHz Kryo) } \\
\text {-Ram: } 4 \mathrm{~GB} \\
\text {-Camera : } 12 \text { megapiksel } \\
\text { - OS: Android } 8.0 \text { (Oreo) }\end{array}$ & $\begin{array}{l}\text { Kinerja aplikasi pada } \\
\text { handphone ini lancar, } \\
\text { button dapat berinteraksi } \\
\text { dengan cepat, kamera } \\
\text { dapat membaca objek } \\
\text { sekitar } 3 \text { detik }\end{array}$ & \\
\hline 2. & $\begin{array}{c}\text { Speksifikasi: } \\
\text { - Octa-core (4x2.3 GHz } \\
\text { Mongoose M2 \& 4x1.7 } \\
\text { GHz Cortex-A53) - } \\
\text { EMEA } \\
\text {-Ram: 4 GB } \\
\text {-Kamera: } 12 \text { MP } \\
\text {-OS: Android 9.0 (Pie) }\end{array}$ & $\begin{array}{l}\text { Kinerja aplikasi pada } \\
\text { handphone ini lancar, } \\
\text { button dapat berinteraksi } \\
\text { dengan cepat, kamera } \\
\text { dapat membaca objek } \\
\text { kurang lebih } 3 \text { detik }\end{array}$ & \\
\hline 3. & $\begin{array}{c}\text { Speksifikasi: } \\
\text { - Octa-core }(4 \times 2.3 \mathrm{GHz} \\
\text { Cortex-A73 \& 4x1.7 GHz } \\
\text { Cortex-A53) } \\
\text {-Ram 4 GB } \\
\text {-Kamera: 25 MP } \\
\text {-OS: Android 9.0 (Pie) }\end{array}$ & $\begin{array}{l}\text { Kinerja aplikasi pada } \\
\text { handphone ini lancar, } \\
\text { button dapat berinteraksi } \\
\text { dengan cepat, kamera } \\
\text { dapat membaca objek } \\
\text { kurang lebih } 3 \text { detik }\end{array}$ & \\
\hline 4. & $\begin{array}{c}\text { Speksifikasi: } \\
\text { - Octa-core 2.2 GHz } \\
\text { Cortex-A53 } \\
\text {-Ram 4 GB } \\
\text {-Kamera: 24 MP } \\
\text {-OS: Android 8.0 (Oreo) }\end{array}$ & $\begin{array}{l}\text { Kinerja aplikasi pada } \\
\text { handphone ini lancar, } \\
\text { button dapat berinteraksi } \\
\text { dengan cepat, kamera } \\
\text { dapat membaca objek } \\
\text { kurang lebih } 3 \text { detik }\end{array}$ & \\
\hline
\end{tabular}

Tahap ini aplikasi telah selesai dibuat. Uji coba usabilitas dilakukan dengan cara melakukan survei pada audiens. Tujuan pengujian ini untuk mengukur tingkat kualitas sistem. 
Tampilan hasil survei terlihat presentatif setiap aspek untuk syarat sebagai perbaikan aplikasi, dimana survei ini dilakukan kepada responden sebanyak 10 orang. Kuesioner yang di buat merujuk pada kategori kuesioner Software Usability Measurement Inventory (SUMI) pernyataan-pernyataan dalam kuesioner SUMI terdiri dari kategori : Effect, Control, Efficiency, Helpfulness, Learnability. Persentase hasil survei ditujukan pada Tabel 8.

Tabel 8. Uji Coba Usabilitas

\begin{tabular}{|c|l|c|c|c|}
\hline \multirow{2}{*}{ No } & \multicolumn{1}{|c|}{ Pertanyaan } & \multicolumn{2}{c|}{ Penilaian } & \multirow{2}{*}{ Persentase } \\
\cline { 3 - 4 } & & Baik & Tidak baik & \\
\hline 1 & Aplikasi ini disajikan dengan menarik & 8 & 2 & $80 \%$ \\
\hline 2 & $\begin{array}{l}\text { Kesesuaian penggunaan warna dan } \\
\text { desain latar belakang (background) }\end{array}$ & 8 & 2 & $80 \%$ \\
\hline 3 & Ketepatan pemilihan jenis tulisan & 8 & 2 & $80 \%$ \\
\hline 4 & Ketepatan pemilihan warna tulisan & 8 & 2 & $80 \%$ \\
\hline 5 & Kesesuaian warna tombol & 9 & 1 & $90 \%$ \\
\hline 6 & Kesesuaian bentuk tombol & 9 & 1 & $90 \%$ \\
\hline 7 & Kesesuaian tampilan animasi & 7 & 3 & $70 \%$ \\
\hline 8 & Kesesuaian ilustrasi gambar & 7 & 3 & $70 \%$ \\
\hline 9 & $\begin{array}{l}\text { Ketepatan fungsi tombol dengan tujuan } \\
\text { menu yang diinginkan }\end{array}$ & 10 & - & $100 \%$ \\
\hline 10 & $\begin{array}{l}\text { Relatif mudah untuk berpindah dari satu } \\
\text { bagian }\end{array}$ & 8 & 2 & $80 \%$ \\
\hline 11 & $\begin{array}{l}\text { Respon Aplikasi terhadap perintah yang } \\
\text { di inginkan }\end{array}$ & 7 & 3 & $70 \%$ \\
\hline 12 & Kegunaan petunjuk cara penggunaan & 8 & 2 & $80 \%$ \\
\hline 13 & Kemudahan pengoperasian aplikasi & 10 & - & $100 \%$ \\
\hline 14 & $\begin{array}{l}\text { Kenyamanan menggunakan aplikasi } \\
\text { secara keseluruhan }\end{array}$ & 8 & 2 & $80 \%$ \\
\hline
\end{tabular}

Penilaian :

1. Effect

: (Pertanyaan Point 1-8) Hasil $=\frac{80+80+80+80+90+90+70+70}{8} \times 100 \%=80 \%$

2. Control

: (Pertanyaan 9-10 pada Tabel 8) Hasil $=\frac{100+80}{2} \times 100 \%=90 \%$

3. Efficiency

: (Pertanyaan 11 pada Tabel 8) Hasil $=70 \%$

4. Helpfulness

: (Pertanyaan 12 pada Tabel 8) Hasil $=80 \%$

5. Learnability: (Pertanyaan 13-14 pada Tabel 8)

$$
\text { Hasil }=\frac{100+8}{2} \times 100 \%=90 \% \text {. }
$$

Dari hasil diatas dapat disimpulkan bahwa media informasi simulasi sistem pernapasan manusia ini layak dipakai untuk membantu pembelajaran bagi siswa, mahasiswa hingga masyarakat yang ingin memperlajarinya, karena dapat menambah daya tarik serta minat.

Bagian terakhir pada program ini dilakukan proses publish yaitu proses publikasi file aplikasi Augmented reality agar dapat dilihat dan dijalankan oleh user umum dan aplikasi dapat didistribusikan melalui toko aplikasi online maupun melalui media perantara lain seperti flashdisk. 


\section{Kesimpulan}

Aplikasi yang dibuat dalam penelitian ini adalah Integrasi Simulasi Augmented reality (AR) Sistem Pernapasan Manusia dengan metode Markerless Based Tracking untuk media informasi sistem pernapasan berbasis android, pembuatan aplikasi ini menggunakan software unity 3D, blender, substance painter dan AR Core. Manfaat dari penelitian ini mempermudah dalam mempelajari sistem pernapasan manusia dengan memanfaatkan smartphone berbasis android yang interaktif dan menarik.

Aplikasi ini telah melalui tahapan proses uji coba diantaranya uji coba struktural pada setiap scene dalam aplikasi yang dibuat, uji coba fungsional yang dilakukan pada tahap button yang ada dalam aplikasi dan uji coba validasi yang dilakukan pada scene aplikasi yang menampilkan objek dan informasi sudah sesuai dengan data (fakta) yang sudah dikumpulkan pada tahap pengumpulan data, sehingga aplikasi ini dapat digunakan oleh user.

Hasil dari uji coba ini juga berdampak pada pengguna yaitu dimana para siswa, mahasiswa hingga orang yang ingin mempelajari sistem pernapasan manusia dapat memperoleh informasi hingga animasi simulasi pernapasan manusia. Pengguna juga dapat dengan mudah mengakses aplikasi hanya dengan memanfaatkan smartphone android.

Selain manfaat yang diperoleh oleh pengguna, penulis juga memperoleh manfaat yang besar. Pembuatan aplikasi ini memberikan pengetahuan lebih bagi penulis tentang pemograman android, dan dapat mengerti tentang perkembangan software android pada smartphone. Penggunaan Unity memberikan kemudahan bagi penulis. Design aplikasi menjadi lebih fleksible dengan fasilitas dari software penunjang tersebut.

\section{Referensi}

[1] Setiadi. 2007. Anatomi Fisiologi Manusia Edisi Pertama. Yogyakarta: Penerbit Graha llmu.

[2] Vitono, H., Nasution, H., dan Anra, H. 2016. Implementasi Markerless Augmented Reality Sebagai Media Informasi Koleksi Museum Berbasis Android (Studi Kasus : Museum Kalimantan Barat). Jurnal Teknik Informatika, 4(2) Program Studi Teknik Informatika. Universitas Tanjungpura Pontianak.

[3] Tosida, E, T., Walujo, A, D., Ardiansyah, D., dan Yuliani. 2018. Media Belajar Batik Berbasis Teknologi Augmented Reality. Prosiding Seminar Ilmiah Nasional Tanggal 27-28.

[4] Oxforddictionaries. 2013. Definion of Smartphone. https://en.oxforddictionaries.com/definition/smartphone - di akses pada 14 Maret 2019 jam 11.45 WIB.

[5] Tosida, E, T., Walujo, A, D., Suriyansyah, M, I., Bayu, H., dan Nurfazri, R. 2018. Pengembangan Media Pembelajaran Digital Kolaboratif Edu Wisata Situ Gede. Charity Jurnal Pengabdian Masyarakat 1(7).

[6] Yanti, S, N., Setiyaningsih, E., dan Sasono, M, H. 2015. Augmented Reality Pada Aplikasi Anatomi Tubuh Manusia (Sistem Reproduksi, Sistem Pencernaan, Sistem Peredaran Darah) Berbasis Android. Jurnal Teknik Informatika ISBN 978-602-99334-4-4. Program Studi Teknik Informatika. Fakultas Teknologi Industri. Universitas Gunadarma.

[7] Kilgus, T., Heim, E., Haase, S., Prufer, S., Muller, M., Seitel, A., Fangerau, M., Wiebe, T., Iszatt, J., Schlemmer, H, P., Hornegger, J., Yen, K., Hein, L, M. 2015. Mobile Markerless Augmented Reality and its Application in Forensic Medicine. Institute for Forensic Medicine and Traffic Medicine, Heidelberg University Hospital, Heidelberg, Germany.

[8] Kiourexidou, M., Natsis, K., Bamidis, P., Antonopoulos, N., Papathanasiou, E., Sgantzos, M., Veglis, A. 2015. Augmented Reality for the Study of Human Heart Anatomy. International Journal of Electronics Communication and Computer Engineering Volume 6, Issue 6, ISSN (Online): 2249-071X, ISSN (Print): 2278-4209. Department of Anatomy. Medical School Aristotle. University of Thessaloniki. Yunani.

[9] Layona, R., Yulianto, B., Tunardi, Y. 2018. Web Based Augmented Reality for Human Body Anatomy Learning. Procedia Computer Science 135 (2018) 457-464. Computer Science Department, School of Computer Science, Bina Nusantara University, Jakarta.

[10] Kurniawan, M, H., Suharjito., Diana., Witjaksono, G. 2018. Human Anatomy Learning 
Systems Using Augmented Reality on Mobile Application. Procedia Computer Science 135 (2018) 80.

[11] Harrell, C., B. K. Ghosh and R.O. Bowden, Jr. 2003. Simulation Using Promodel, 2nd ed. McGraw-Hill. Singapore.

[12] Huda, I., dan Fuadi, Y. 2019. Penerapan Teknologi Augmented Reality Pada Aplikasi Media Pembelajaran Mikrokontroler Berbasis Android Dengan Paltform ARCore. Jurnal Teknologi Informasi dan IImu Komputer, Volume 17, Nomor 1, ISSN 1693-2277. Departemen Teknik Elektro dan Informatika. UGM. Yogyakarta.

[13] Lestari, E, S., dan Kistinnah, I. 2010. Makhluk Hidup dan Lingkungannya, Buku Ajar SMA/MA Kelas XI. Pusat Perbukuan Departemen Pendidikan Nasional: Jakarta. 